\title{
Model of Employee Work EngagementTheory in Indonesia
}

\author{
Alfiatun Sarasatia 1 , Djamaludin \\ Ancok $^{\mathrm{b}}$ Nilam $^{\mathrm{c}}$ \\ arralfiatun23@gmail.com \\ bdjamaludin@staff.gunadarma.ac.id \\ cnilam@staff.gunadarma.ac.id \\ a cDoctoral in Psychology, Gunadarma University, J1.Margonda Raya 100 Depok 16424, Indonesia \\ b,cPost Graduate Program in Psychology, Gunadarma University, Jl.Margonda Raya 100 Depok 16424, Indonesia
}

Abstract

An organization requires to conduct some innovate business activities, be passionate and having a high commitment and loyal into the organization. it has to achieve competitive advantage in the global market through managing quality human resources. In the meantime COVID-19 has left the globe in a situation of despondency. Human resource managers are struggling to curb this renunciation of employees and grappling with reduced employee engagement. This article objective is to test and to analyse a model of employee engagement theory in Indonesia. Survey was conducted to 247 employees og state owned enterprise who were selected using by convenience sampling method. Primary data were collected through distribution a set questionare via google form. Then data were analysed by structural equation model. The results show that perception of organizational justice and perceived organizational support are the antecedents variabel of the work engagement and transformational leadership has big indirect effect through the perception of organizational support on the work engagement. The study can be used as a reference for similar studies to compare other interrelated variables among business organization and implementation some pragmatis implication for Ministry of man power.

Keywords: employee work engagement, organizational justice, perceived organizational support, andleadership

\section{Introduction}

The world continues to experience development and progress in all its aspects, including in the industrial environment, where new terms emerge, namely industry 4.0 and society 5.0. In its development, companies in the world are required to compete fiercely in order to survive in their business. Pereira, Lima, and Charrua-Santos (2020) say that the industry

4.0 brings progress in improving services, equipment and products to improve people's quality of life to be happier, motivated, satisfied, and have more free time. Then, society 5.0 is defined as an era where a human- centered society can increase economic development and find solutions to solve social problems using a system that integrates the virtual world and the real world (Hendarsyah, 2019).

Adequate literacy skills must also be mastered because they show elements of soft skills or individual character development to be able to collaborate, be adaptive, and innovative (Ellitan, 2020). This requires all organizations to continuously adapt to changes and accommodate various existing needs, including the need for a quality workforce.

Various organizations with various types of businesses in Indonesia compete and try to survive with various strategies to adapt to industry 4.0 and society 5.0. Therefore, new approaches to human resource management are inevitable.

Industry trends are changing very rapidly in the era of the industrial revolution 4.0, this results in very heavy pressure for companies engaged in the printing sector. Both private and state owned. This is because the market is no longer dependent on information presented through print media, but through the internet, online, virtual, and so on. So that the market for printing services, especially general printing in Indonesia, is experiencing a slump and ultimately affects production and production income for the company, especially as it is today when the covid-19 pandemic began to spread, companies engaged in the security and general printing business must make extra efforts to keep the production process running.

An organization puts forward a code of ethics and employee behavior that is in line with Ellitan's

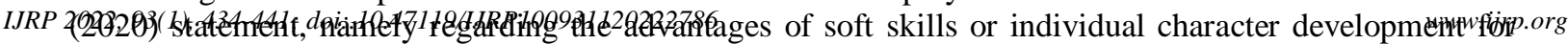
collaborative, adaptive, and innovative. On the way to developing individual characters who have qualities 
in accordance with organizational values, of course there are obstacles. For example, the demonstration that took place at manufacturing Companies in Indonesia.

The demonstration activities disrupted production and marketing activities within the company and it is the responsibility of the policy makers in the organization to review the system that has been running within the organization. Demo impact on sales performace then especially customer services. There was a delay in the production schedule and product delivery, which led to many complaints from customers. These illustrated the negative psichology and dissatisfaction of employees in the organization. According to Garg, Dar, and Mishra (2017), job satisfaction is the main key to employee work engagement. Research by Dewinda, Ancok, and Widyarini (2020) also states that there is a significant influence between job satisfaction and employee work engagement. Demo activity data also illustrated the existence of a nonphysical work environment that is not good (unbalanced work environment), definitely also it described the bad relationship between employees and their superiors indeed CEO. The unfavorable work environment can be trigger into low (weak) employee engagement (Kusendi \& Ispurwanto, 2018).

Actually demonstration phenomenon is very often carried out by employees or employee unions. These can lead to strike activities, usually caused by several things, namely financial factors, physical factors, psychological factors, and social factors (Jemadi \& Hidayati, 2012). Group cohesiveness is one of the social factors that can trigger demonstrations by employees. In addition, the work engagement factor, which is characterized by a desire to leave the organization, as well as negative perceptions about the organization can also trigger demonstrations by employees.

Employee work engagement is a condition in which a person has a positive mind, so that he is able to express himself physically, cognitively, and affectively in doing work, including enthusiasm (vigor), dedication and absorption (Schaufeli \& Bakker, 2003).

All tables should be numbered with Arabic numerals. Headings should be placed above tables, left justified. Leave one line space between the heading and the table. Only horizontal lines should be used within a table, to distinguish the column headings from the body of the table, and immediately above and below the table. Tables must be embedded into the text and not supplied separately. Below is an example which authors may find useful.

The purpose of this study was to produce a theoretical model of work engagement of employees in manufactur entities in Indonesia. Based on the results of the theoretical model test obtained, it can then be stated the magnitude of the regression in the relationship between variables, and also the amount of the effective contribution received by each dependent variable from the independent variables.

\section{Research Elaboration}

Data collection in this study was carried out using a questionnaire in the form of a Likert scale. The Likert scale is a scale that measures self-report attributes by providing various responses to a statement or a series of statements (Croasmun \& Ostrom, 2011). The Likert scale is the most commonly used measurement method, providing a convenient way of measuring unobservable constructs (Jebb, $\mathrm{Ng}, \&$ Tay, 2021). The questionnaires in this study included a list of respondents' self-identity, employee engagement scale, perceived organizational justice scale, transformational leadership scale, group cohesiveness scale, and perceived organizational support scale.

Work engagement of employees to the organization and the values in it, seen from the attitudes and thoughts of employees to be committed to achieving organizational goals with enthusiasm and dedication. Work engagement Employees in this study were identified based on scores on the Utrecht Work Engagement Scale (UWES) which were arranged based on the dimensions of employee work engagement according to Schaufelli and Bakker (2006), namely vigor, dedication, and absorption. The higher the value obtained, the higher the work engagement of employees, and vice versa, the lower the value obtained, the lower the work engagement of employees.

Group cohesiveness is a feeling of togetherness of individuals towards all group members, where individuals prioritize meaning, bonds, and common interests among group members over

personal interests. The group cohesion of employees in this study is known based on scores on the Group Cohesion Questionnaires (GCQ) scale which is based on the dimensions of group cohesion according to Charles and De Paola (2000), namely the dimensions of task cohesion and social cohesion. The higher the value obtained, the higher the cohesiveness of the group of employees, and vice versa, the lower the value obtained, the lower the cohesiveness of the group of employees.

The scale used to measure group cohesion in this study was adapted from the Group Cohesion Questionnaires (GCQ) compiled by Carless and Paola (2000), based on the dimensions of group cohesion, where there are dimensions of task cohesion and social cohesion.

The scale used to measure transformational leadership in this study adapts the Multifactor Leadership Questionnaire scale compiled by Avolio and Bass (2020) based on the dimensions of transformational leadership according to Bass and Riggio (2006), namely idealized influence, inspirational motivation), intellectual stimulation (intellectual stimulation), and individualized consideration.

Employees' perceptions of organizational justice in this study are known based on scores on the Justice Measure. Items scale compiled by Colquitt (2001) based on the dimensions of perceived organizational justice according to Muchinsky (2006), namely perceptions of procedural justice, distributive justice. As 
well as interactional justice which includes perceptions of interpersonal justice and informational justice. The higher the value obtained, the higher the perception of organizational justice for BUMN employees, and vice versa, the lower the value obtained, the lower the perception of organizational employees.

Perceived organizational support of employees in this study is known based on scores on the Survey Perceived Organizational Support (SPOS) scale which is based on the dimensions of perceived organizational support according to Rhoades and Eisenberger (2002), namely fairness, supervisor support, and organizational rewards and working conditions (organizational rewards \& working conditions). The higher the value obtained, the higher the perception of organizational support for employees, and vice versa, the lower the value obtained, the lower the perception of organizational support for employees.

Sampling in this study used a non-probability sampling technique with convenience sampling type. According to Robinson (2014), convenience sampling is a non random way to ensure that the participants in the research sample represent a certain category of population.

Primary data collection in this study was carried out by distributing questionnaires in the form of google form to 247 employees who were selected randomly using purposive sampling technique with a minimum working period of 2 years and domiciled in Jakarta, Bogor, Tangerang and Bekasi.

\section{Result and Findings}

The results of the classical assumption test that have been carried out are starting from the data adequacy test, normality, validity and reliability test to the fit and goodness test of the research model showing the numbers as good indicators so that the analysis for hypothesis testing can be continued. 
FULL MODEL

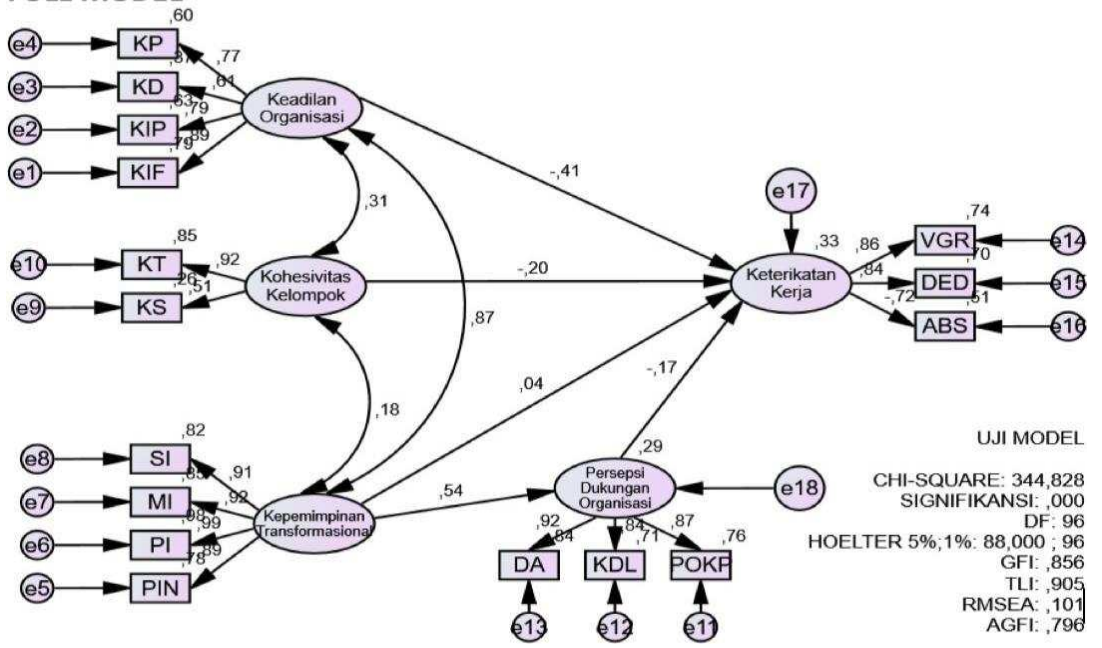

Figure 1. Stuctural Equation Model

Table 11.

Standardized Regression Weights: (Group number 1 - Default model)

\begin{tabular}{|ll|rrrr|}
\hline & & Estimate & S.E. & C.R. & P \\
\hline $\begin{array}{l}\text { Perception of Organization } \\
\text { support }\end{array}$ & $<--$ Transformational leadership &, 280 &, 032 & 8,663 & $* * *$ \\
Work engagement & $<---$ Group Cohesian &,- 160 &, 059 & $-2,707$ &, 007 \\
Work engagement & $<--\begin{array}{l}\text { Perception of Organizationa } \\
\text { justice }\end{array}$ &,- 155 &, 062 & $-2,498$ &, 012 \\
Work engagement & $<--$ Transformational leadership &, 012 &, 049 &, 247 &, 805 \\
Work engagement & $<--\begin{array}{l}\text { Perception of Organization } \\
\text { support }\end{array}$ &,- 103 &, 045 & $-2,268$ &, 023 \\
\hline
\end{tabular}

\section{SOBEL TEST}

\begin{tabular}{|c|c|c|c|c|}
\hline Input: & & Test statistic: & Std. Error: & p-value: \\
\hline a 0.540 & Sobel test: & -3.66586898 & 0.02489451 & 0.0002465 \\
\hline$b-0.169$ & Aroian test: & -3.65975145 & 0.02493612 & 0.00025246 \\
\hline$s_{\mathrm{a}} 0.032$ & Goodman test: & -3.6720173 & 0.02485282 & 0.00024064 \\
\hline$s_{\mathrm{b}} 0.045$ & Reset all & \multicolumn{3}{|c|}{ Calculate } \\
\hline
\end{tabular}


Based on the results of the hypothesis test in Table 11, it turns out that the variables of organizational justice perception, perceived organizational support and group cohesion are antecedents to work engagement. The variable perception of organizational justice is the strongest predictor variable on work engagement, and the weakest predictor is the perceived organizational support variable. Transformational leadership is not able to explain work engagement.

Based on the results of the Sobel test, it turns out that the p-value $<0.005$ means that Transformational Leadership mediates the relationship between Perceived Organizational Support and Work Engagement.

Employee work engagement is a condition in which a person has a positive mind, so that he is able to express himself optimally in doing work and can display enthusiasm (vigor), dedication (dedication), and absorption of work (absorption) (Schaufeli \& Bakker, 2003). Job engagement is an important thing to study because employees who have high work engagement will produce good performance, and ultimately organizational goals can be achieved (Satata, 2021).

According to Schaufeli (2012), employee work engagement is considered the positive antithesis of burnout, employees who are active with enthusiasm and have a positive relationship with their work, will not feel stressed and will see their work as a challenge. Therefore, Engagement is characterized by the energy, involvement, and efficacy of employees, where these three things are the direct opposite of the burnout dimension, namely fatigue, cynicism, and reduced achievement (Maslach \& Leiter, 2012).

Employees who have work engagement and are accompanied by good self-efficacy will have good personal initiative in doing work, which in turn leads to higher individual performance (Lisbona, Palaci, Salanova, \& Frese, 2018). Bakker and Demerouti (2008) add that there are several reasons that employees who are engaged with their work perform better than employees who are not engaged. This can be seen from the positive emotions that are often experienced by employees, employees have better health, employees can create their own work resources and personal resources, and finally employees can indirectly "transmit" their attachments to other employees.

Noor, Robiansyah \& Syaharuddin (2020) reveal that each dimension of the perception of organizational justice, namely the perception of distributive, procedural, and interactional justice is a factor that can be an antecedent for employee work engagement. This statement is supported by research by Roy \& Tiwari (2020) which reveals that there is a strong and positive relationship between perceptions of organizational justice and employee work engagement, and it is also explained that perceptions of distributive, procedural, and interactional justice are interrelated with each other. perceptions of distributive and interactional justice have more influence than perceptions of procedural justice.

There are several studies that also support the influence of perceptions of organizational justice on employee work engagement, howevernthere are different results related to the dimensions that exist in the perception of organizational justice on employee work engagement. Ozer, Ugurluoglu \& Saygili (2017) claim that an increase in the perception of organizational justice in turn significantly affects the level of employee work engagement, the most significant influence is from the perception of procedural justice, then followed by the perception of distributive and interactional justice. Then, Lyu (2016) said that the three dimensions of perceived organizational justice, namely perceptions of distributive, procedural, and interactional justice have a positive effect on employee work engagement. Meanwhile, Alvi and Abbasi (2012), show that the perception of distributive justice has a significant positive effect on employee work engagement.

In addition, there are other factors that can affect employee work engagement, one of which is the leadership style possessed by leaders in an organization. According to Datche and Mukulu (2015), transformational leadership style has a positive relationship with employee work engagement. This is also supported by the research of Bui, Zeng, and Higgs (2017) that transformational leadership has a significant influence on employee work engagement, and therefore, leaders with transformational leadership styles can redesign the work context so that work becomes more meaningful, and ultimately can reduce organizational losses caused by unattached employees (Ghadi, Fernando, \& Caputi, 2013). 
Leadership is considered an important and inevitable aspect for the progress of an organization. Leaders with a transformational leadership style create greater engagement in the work of their members resulting in higher efficiency and satisfaction, thereby increasing the overall level of employee engagement in the organization (Singh, 2019). It is known that the transformational leadership style shown by superiors in an organization can make employees more attached to the organization (Permadi, Musadieq, \& Prasetya, 2018). Therefore, it can be said that organizational leaders must have transformational attributes and have good relationships and communication with employees because leaders with transformational leadership styles can inspire employees to achieve the expected results, and this gives employees the confidence to do a job. and the ability to make decisions (Khan, Rehmat, Butt, Farooqi, \& Asim, 2020).

Furthermore, Bernarto, Bachtiar, Sudibjo, Suryawan, Purwanto, \& Asbari (2020) revealed that transformational leadership applied by leaders in an organization can increase the perception of employee organizational support for the organization. Transformational leadership can result in greater involvement in employees' work (Toufaili, 2017) and make employees feel more supported and valued by the organization, and ultimately can increase employees' emotional attachment to the organization. This is because transformational leadership is known to have a significant positive relationship with intrinsic motivation and also employee performance (Khan, Rehmat, Butt, Farooqi, \& Asim, 2020).

Transformational leaders are leaders who can motivate their employees to work for a common goal and for higher self-actualization needs. Transformational leaders can inspire group members with future organizational goals and this can have an effect in the early stages of forming cohesiveness group, namely achieving a common goal (Pillai \& Williams, 2004). Transformational leadership can affect group cohesiveness, which in turn can increase the group's potential in the organization (Garcia-Guiu, Moya, Molero, \& Moriano, 2016).

It is known that competition in organizations is needed to achieve the vision and mission of the organization, where to develop these relationships requires a process of reciprocal relations between the organization and employees. The employee's perception of the organization where he works, describes the opinion of the employee about the organization where he works. Organizational justice which consists of dimensions of distributive, interpersonal, and informational justice has a higher influence on individuals who have a high level of work group cohesion (Andrews, Kacmar, and Blakely, 2008). Ismail, Baki, and Omar (2018) also reveal that organizational justice felt by employees in an organization can contribute to the level of group cohesiveness in the organization, where involvement between employees and their environment can affect one aspect of organizational behavior, namely group cohesiveness.

\section{Conclusion}

The model of this research provides a very large empirical contribution, all exogenous variables have a significant effect on employee work engagement in 3 SOEs in printing business in Indonesia. Only one variable namely transformational leadership has no impact on work engagement. It indicates that many of the demonstrations that reveal are suspected of being non- transformational leadership, the possibility of transactional leadership, need further research.

This research provides insight and useful input for the development of business psychology. This research is also expected to be a material for learning and applying the employee engagement model and developing the field of study in the field of Industrial and Organizational Psychology. The results of this study provide some recomendations for consideration in formulating policies related to the management of employee engagement and placement of directors or leadership positions in State-Owned Enterprises (BUMN), especially SOEs in the field of printing security documents with an operational permit from BIN RI through fit and proper test. 


\section{References}

Alvi, A. K., \& Abbasi, A. S. (2012). Impact of organizational justice on employee engagement in banking sector of pakistan. Middle-East Journal of Scientific Research 12(5), 643-649.

Andrews, M. C., Kacmar, K. M., \& Blakely, G. L. (2008). Group cohesion as an enhancement to the justice-affective commitment relationship. Group \& Organization Management 33(6), 736 - 755.

Aube, C., Rousseau, V., \& Morin, M. E. (2007). Perceived organizational support and organizational commitment, the moderating effect of locus of control and work autonomy. Journal of Managerial Psychology 22(5), $479-495$.

Bakker, A. B., \& Demerouti, E. (2008). Towards a model of work engagement. Career Development International 13(3), 209 - 223.

Bakker, Arnold B., Leiter, Michael P. (2010). Work Engagement: A Handbook of Essential Theory and Research. New York: Psychology Press.

Bass, B. M., \& Riggio, R. E. (2006). Transformational leadership, $2^{\text {nd }}$ ed. New Jersey: Lawrence Elbaum Associates.

Baumeister, R., \& Vohs, K. D. (2007). Encyclopedia of social psychology. Los Angeles: Sage Publications, Inc.

Bernarto, I., Bachtiar, D., Sudibjo, N., Suryawan, I. N., Purwanto, A., \& Asbari,

M. (2020). Effect of transformational leadership, perceived organizational support, job satisfaction toward life satisfaction: eviden from Indonesian teachers. International Journal of Advanced Science and Technology 29(3), 5495 - 5503.

Bui, H. T. M., Zeng, Y., \& Higgs, M. (2017). The role of person-job fit in the relationship between transformational leadership and job engagement. Journal of Managerial Psychology 32(5), 373-386.

Carless, S. A., \& Paola, C. D. (2000). The measurement of cohesion in work teams. Small Group Research 31(1), 71-88.

Colquitt, J. A. (2001). On the dimensionality of organizational justice: A construct validation of a measure. Journal of Applied Psychology 86 (3), $386-400$.

Croasmun, J. T., \& Ostrom, L. (2011). Using likert-type scales in the social sciences. Journal of Adult Education 40(1), $19-22$.

Datche, A. E., \& Mukulu, E. (2015). The effects of transformational leadership on employee engagement: A survey of civil service in Kenya. Issues in Business Management and Economics 3 (2), 9-16.

Eisenberger, R., \& Stinglhamber, F. (2011). Perceived organizational support: Fostering enthusiastic and productive employees. America: American Psychological Association.

Eisenberger, R., Huntington, R., Hutchison, S., Sowa, D. (1986). Perceived organizational support. Journal of Applied Psychology 71(3), $500-507$.

Ellitan, L. (2020). Competing in the era of industrial revolution 4.0 and society 5.0. Jurnal Maksipreneur 10(1), $1-12$.

Federman, B. (2009). Employee engagement: A roadmap for creating profile, optimizing performance, and increasing loyalty. San Fransisco: John Wiley \& Sons, Inc.

Fitzpatrick, A. R. (1983). The meaning of content validity. Applied Psychological Measurement 7(1), $3-13$.

Flake, J. K., Pek, J., \& Hehman, E. (2017). Construct validation in social and personality research: Current practice and recommendations. Special Issue Article 8(4), 370 - 378.

Garcia-Guiu, C., Moya, M., Molero, F., \& Moriano, A. (2016). Transformational leadership and group potency in small military units: The mediating role of group identification and cohesion. Journal of Work and Organizational Psychology, $1-8$.

Garg, K., Dar, I. A., \& Mishra, M. (2017). Job satisfaction and work engagement: A study using private sector bank managers. Advances in Developing Human Resources, $1-14$.

Ghadi, M., Y., Fernando, M., \& Caputi, P. (2013). Transformational leadership and work engagement: The mediating effect of meaning in work. Leadership \& Organization Development Journal 34(6), 532-550.

Ghani, N. A. A., \& Hussin, T. A. B. S. R. (2009). Antecedents of perceived organizational support (Antécédent de la perception de soutien organisationnel). Canadian Social Science 5(6), $121-130$.

Ha, J., \& Ha, J. (2015). Organizational justice-affective commitment relationship in a team sport setting: The moderating effect of group cohession. Journal of Management \& Organization 21(1), 107 - 124.

Hanggoro, R. (2002). Tipe kepemimpinan dalam organisasi pembelajaran. Journal of Applied Psychology 73, 695-702.

Hay, I. (2006). Transformational leadership: Characteristics and criticisms. E- Journal of Organizational Learning and Leadership 5(2), $1-19$.

Hendarsyah, D. (2019). E-commerce di era industri 4.0 dan society 5.0. IQTISHADUNA: Jurnal Ilmiah Ekonomi Kita 8(2), 171 - 184.

Hughes, R. L., Ginnett, R. C., \& Curphy, G. J. (2009). Leadership: Enhancing the Lessons of Experience, 7th edition (terjemahan). Jakarta: Salemba Humanika.

Ismail, M., Baki, N. U., \& Omar, Z. (2018). The influence of organizational culture and organizational justice on group cohession as perceived by merger and acquisition employees. Organizations and Markets in Emerging Economies 9(2), 233 - 250.

Jebb, A. T., Ng, V., \& Tay, L. (2021). A review of key likert scale development advances: 1995-2019. Frontiers in Psychology $12,1-14$.

Khan, H., Rehmat, M., Butt, T. H., Farooqi, S., \& Asim, J. (2020). Impact of transformational leadership on work performance, burnout and social loafing: A mediation model. Future Business Journal 6(40), 1 - 13.

Kinicki \& Fugate. 2018. Organizational behavior: A practical, problem-solving pproach. New York: McGraw Hill Education.

Lisbona, A., Palaci, F., Salanova, M., \& Frese, M. (2018). The effects of work engagement and self-efficacy on personal initiative and performance. Psicothema 30(1), 89 - 104.

Lyu, X. (2016). Effect of organizational justice on work engagement with psychological safety as a mediator: Evidence from china. Social Behavior and Personality 44(8), $1359-1370$.

Muppidathi, P., \& Krishnan, V. R. (2015). Effect of transformational leadership on followers' collective efficacy and group cohessiveness: Social identity as mediator. Humanities and Social Sciences Behaviour 4(3), 363 - 372. 
Nilwala, N., Gunawardana, K., \& Fernando, R. I. S. (2017). Scale for measuring transformational leadership in public sector organizations in sri lanka: With special reference to ministries of western provincial council. International Journal of Management and Sustainability 6(4), $63-74$.

Noor, A. F., Robiansyah, \& Syaharuddin, Y. (2020). Pengaruh organizational justice terhadap tingkat employee engagement. Jurnal Manajemen 12(2), $199-208$.

Ozer, O., Ugurluoglu, O., \& Saygili, M. (2017). Effect of organizational justice on work engagement in healthcare sector of turkey. Journal of Health Management 19(1), 1-11.

Panatik, S. S., Ahmad, U. N. U, Ashari, H., Azhar, Z. N., Muhammad, S. N., \& Yusof, F. M. (2017). The effect of organizational justice on work engagement: An empirical investigation among female engineers in Malaysia. Advanced Science Letters 23(9), 8634 - 8641.

Park, Y. K., Song, J. H., Lim, D. H. (2016). Organizational justice and work engagement: the mediating effect of self-leadership. Leadership \& Organization Development Journal 37(6), 1 - 35.

Pemecutan, A. A. G. G., Dharmanegara, I. B. A., \& Udayana, I. G. B. (2016). The role of perceived organizational support to increase effect of organizational justice dimension on organizational citizenship behavior. IOSR Journal of Business and Management 18(8), $57-68$.

Pereira, A. G., Lima, T. M., \& Charrua-Santos, F. (2020). Industry 4.0 and society 5.0: Opportunities and Threats. International Journal of Recent Technology and Engineering (IJRTE) 8(5), 3305 - 3308.

Pillai, R., \& Williams, E. S. (2004). Transformational leadership, self-efficacy, group cohessiveness, commitment, and performance. Journal of Organizational Change Management 17(2), 144 - 159.

Rafia, R., Sudiro, A., Sunaryo. (2020). The effect of transformational leadership on employee performance mediated by job satisfaction and employee engagement. International Journal of Business, Economics and Law 21(5), 119 - 125.

Rhoades, L, \& Eisenberger, R. (2002). Perceived organizational support: A review of the literature. Journal of Applied Psychology 87, 698-714..

Roy, A., \& Tiwari, A. (2020). Organization justice impact on employee work engagement. International Journal of Advanced Science and Technology 29(2), $2694-2700$.

Saks, A. (2006), Antecedents and consequences of employee engagement. Journal of Managerial Psychology 21(7), 600-619.

Satata, D. B. M. (2021). Employee engagement as an effort to improve work performance: Literature review. International Journal of Social Sciences 2(1), $41-49$.

Schaufeli, W. B. (2012). Work engagement. What do we know and where do we go?. Romanian Journal of Applied Psychology 14(1), 3 10 .

Schaufeli, W., \& Bakker, A. (2004). Uwes: Utrecht work engagement scale, preliminary manual. Occupational Health Psychology Unit, Utrecht University.

Schaufeli, W.B., \& Bakker, A.B. (2003). UWES - Utrecht Work Engagement Scale: Test Manual. Unpublished Manuscript: Department of Psychology, Utrecht University.

Suifan, T. S., Abdallah, A. B., \& Janini, M. A. (2018). The impact of transformational leadership on employees' creativity: The mediating role of perceived organizational support. Management Research Review 41(1), 113 - 132.

Sun, L. (2019). Employee engagement: A literature review. International Journal of Human Resource Studies 9(1), 63 - 80.

Sunyoto, D., Tjahjono, H. K., Qodri, Z. M. E., Prajogo, W., \& Hadi, S. (2021). Group engagement based on social exchange theory: Antecedents and consequences. Journal of Leadership in Organizations 3(1), 43 - 57.

Tang, T. L. P., \& Sarsfield-Baldwin, L. J. (1996). Distributive and procedural justice as related to satisfaction and commitment. S.A.M. Advanced Management Journal, 61 (3), 25-50.

Toufaili, B. E. (2017). The effects of transformational leadership on organizational performance: A theoretical approach. Proceedings of the International Management Conference 11(1), 153 - 163 